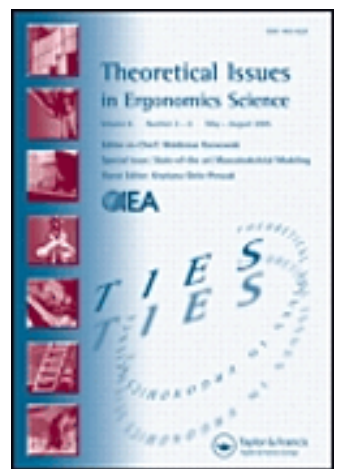

\title{
The Human Centric Lighting Approach for the Design of Age- Friendly Products
}

\begin{tabular}{|r|l|}
\hline Journal: & Theoretical Issues in Ergonomics Science \\
\hline Manuscript ID & TTIE-2019-0004.R3 \\
\hline Manuscript Type: & Research Paper \\
\hline Keywords: & $\begin{array}{l}\text { Human centric lighting, ergonomic design, new product development, old } \\
\text { age, domestic lighting system }\end{array}$ \\
\hline
\end{tabular}

\section{SCHOLARONE \\ Manuscripts}




\title{
The Human Centric Lighting Approach for the Design of Age-Friendly Products
}

\begin{abstract}
As world's societal wellbeing is growing, in the near future the 'seniors condition' will force designers and companies to rethink the way they conceive, produce and sell products. This condition is fundamental for some strategic markets like the lighting domain. In this scenario, Human Centric Lighting (HCL) approach considers both seniors' biological aspects and technological advances to develop eco-efficient solutions that consider visual and non-visual aspects of light. This paper show the use of HCL as a new design approach able to help designers in the development of a wide range of lighting solutions; from the analysis of human conditions, this paper describes the research process used to design a HCL-Based System that perfectly meets seniors' needs.
\end{abstract}

Keywords: Human centric lighting; ergonomic design; new product development; old age, domestic lighting system

\section{Relevance for Human Factors and Ergonomics}

In the near future, the aging of the world population will influence Human Factors and Ergonomics (HF/E) studies. This paper introduces the Human Centric Lighting (HCL) as a new design approach useful to meet both biological aspects of seniors and technological advances related to the design of eco-efficient lighting solutions. This study is therefore in line with HF/E tradition, facing contemporary human's issues with traditional ergonomic studies and recent holistic design approaches, which are in line with the notions of Human Centred Design (HCD).

\section{Lighting Design in Elderly Sectors: Between Human Wellbeing and Product Innovation}

The relationship between light and human wellbeing has been widely documented in many studies (i.e. Veitch et al., 1993; Veitch and Gifford, 1996; Wirz-Justice, 1996; van Bommel and van den Beld, 2004; Brainard and Provencio, 2008; Wirz-Justice and Fournier, 2010; Christoffersen, 2011; Pechacek et al., 2013) and concerns medical, 
anthropological, social and psychological factors. But only recently the artificial light's comfort increased in importance for design and HF/E domains (i.e. Ticleanu et al., 2015) supporting the people's interaction processes with products and environments.

Aging of people is highlighting new design challenges; new holistic and inclusive wellbeing-oriented design strategies are needed. Accordingly the rising class of 'seniors' will be one of the most important categories of customers that will use domestic products (Moschis et al., 1997), including lighting ones.

Human Centric Lighting (HCL) is a new design approach aimed to satisfy the psychophysiological and emotional needs of people (Srivastava, et al., 2012). Seeing the seniors' condition, HCL approaches the study of artificial light aiming to improve the life of people in every aspect where light, as designable element, can be an essential factor. HCL considers both visual and non-visual effects of light that are less considered by design literature, producing higher controls on intrinsic lighting characteristics. HCL can be a useful approach to review seniors' psychophysical and social difficulties in an inclusive way, supporting the idea of seniors as a new group able to address the research and development of new highly-usable solutions for all.

\section{Aims and Methodology}

This work proposes a proactive convergence between the socio-psychophysical conditions of seniors with the new positive vision introduced by recent technological advances in lighting industry. It recognises the role of Design Research and Human Factors in connecting the social needs expressed by seniors (market demand), with the new enabling power offered by current industry advances (market offering). Accordingly, the HCL is a valid alternative to develop enabling age-friendly solutions, with the idea that products easily usable by seniors are also highly usable by youngers.

The aim of this work is to introduce the HCL as useful design approach usable to face the complex issues connected to the seniors' interaction with lighting products i.e. dimensioning of elements, estimation of light flux, etc. - as well as to create ergonomically performing products that boost personal dignity and independence. This work is divided into two phases: analytical and design, described as follow:

- The analytical phase defines the scientific structure of this work; it aims to understand all biological, design and technical elements on seniors' condition. 
- The design phase aims to develop a new HCL-oriented age-friendly lighting system for seniors. Notions belonging to Ergonomic Design, Engineering and Industrial Design domains are combined with HCL approach.

\section{Seniors and Design Opportunities}

The concept of old age has been repeatedly reviewed over years and, in principle, it is used to describe someone aged 65, or more, having some generic physical age-related difficulties like: physical disabilities, difficulties in interacting with technologies, etc. People live better and longer than past and, in the scenario of 'active aging', seniors are active, both physically and professionally, playing active roles in the social, cultural and politic life.

In 2017 the world population reached 7.6 billion and over 13\% are people aged 60 , or more. UN's estimations expects that between 2017 and 2050, half of the world's population growth will occur in only nine countries, including: Nigeria, Democratic Republic of Congo, Pakistan, Ethiopia, Tanzania, United States of America, Uganda and Indonesia (UN, 2017). By 2050 the number of people aged 80 or more will triple (425 million); this number will be seven times higher by 2100 (909 million). Finally, the average age will continue to rise from 29.6 years in 2015 to 36.1 in 2050 (UN 2017).

From the design point of view, the previous data allow to anticipate what kind of actions companies should do in the near future to maintain their marker competitiveness and, then, what kind of strategies they could adopt in order to meet the seniors' needs. The simplistic design approach used till now must be re-discussed; traditional approach conceives 'exclusive' - not inclusive - solutions that do not meet people's real needs, being out of markets demand and not in line with end-users' real psychophysical and social condition. Companies still have an idea of senior as 'weak old person' needing of simplified, elementary or extremely easy-to-use solutions. On this human-centered design idea, Gretchen Anderson (2006) stated:

Even as technology has gotten smaller, more powerful and cheaper, the design aesthetic for the pre-Boomer generation is still exemplified by orthopedic shoes. [...] As our society matures, and Baby Boomers start swelling the ranks of the 
'elderly', we will have to start coming up with better-looking, more useful products for seniors.

$[\ldots]$ Boomers will bring their great influence and purchasing power to bear on businesses and demand experiences that are more elegant and agile. [...].

We need exercise equipment for the mind and body, not just products that treat the inevitable decline. $[\ldots]$ Our challenge is to make their lives meaningful.

The thesis expressed by Anderson follows, in some way, a part of the recent Design literature focused in the area of Universal Design and Inclusive Design (i.e. Seidel et al., 2010; Mieczakowski and Clarkson, 2013); these works demonstrated that seniors have a own dignity, they want to be considered as active people and, mostly, they have quantifiable needs and wishes like younger demographic groups. If turned to the production domain, seniors expect to use 'inclusive solutions', which are solutions suitable for all, not 'solutions designed for' (Rossi and Barcarolo, 2019).

Although this social change is evolving the demand for new products, many companies do not recognize the value expressed by the senior class; at the moment, they only recognize that it will be essential to correctly intercept this issue in the future (Gassmann and Reepmeyer, 2011). Concentrating the strategic development of products only on young customers is wrong, as well as it is wrong to conceive and sell products that are exclusive for elders. In fact, seniors do not want to feel themselves belonging to a 'special category'.

\section{Synthetic Overview on Biological Factors of Lighting Stimuli and Seniors' Perception of Wellbeing}

A fundamental factor connecting the human reactions to light stimuli is the circadian rhythm, which is defined in chronobiology as the 'internal clock of the human body' (Lemmer, 2010). The circadian rhythm regulates physiological and behavioural rhythms like: sleep-wake cycle, vigilance, daily performance, hormone production, body temperature and metabolism. Environmental light is therefore the most powerful factor for its stabilization.

Light signals arrive at the brain following two ways: the first one is the optic nerve (POT), through signals coming from photoreceptors, and leads to the visual cortex and the retinohypothalamic tract; the second one is via the signals of the 
intrinsically photosensitive Retinal Ganglion Cells (ipRGC), which are a third family of photoreceptor cells leading the signals to the suprachiasmatic nucleus (SCN). SCN can be considered as the real internal clock of mammals and it is responsible for various physiological processes (Bernanrd et al., 2007). In terms of production, four hormones are fundamental: melatonin, which regulates wakefulness (Hardeland et al., 2006); cortisol, which influences the stress level (de Weerth et al., 2003); dopamine, which regulates human's pleasure, vigilance and muscle coordination (Hirsh et al., 2010); serotonin, which regulates, for example, the need of carbohydrates (Pontes et al., 2010).

Studies have also confirmed that both illumination and duration of light exposure are relevant for the circadian rhythm (Warman et al., 2003). Assuming long exposures, domestic lights can condition people's circadian rhythm. Consequently, night light exposure could negatively affect on the production of melatonin.

The perception of light influences the life of people; it stimulates their awareness on the time of day and, mostly, on how much energy they should have in that exact moment (energy need - i.e. hunger). In 2012, the American Medical Association (AMA) documented the need to develop modern technologies to minimise the interruption of circadian rhythm (Blask et al., 2012).

A recent study (Scheuermaier et al., 2011) has shown that seniors spend roughly $38 \%$ of their waking hours in moderate room light intensity ( $<100$ lux $)$ and more than the $15 \%$ with brighter light levels ( $\geq 1000$ lux), which is equivalent to sunlight. Accordingly, traditional artificial lights are inadequate for seniors' specific needs. Moreover, for elderly people, the ability to focus objects tends to decrease, as well as the ability to compensate the lower levels of brightness and the detection of colours. Diffused light acts on the chromatic perception reducing the differences of colours at the edges of silhouettes. Thus, to have an appropriate visual acuity, a person aged 60, or more, needs of a 2-5 time higher level of light than a person aged 20 (van de Kraats and van Norren, 2007).

Circadian rhythm is also influenced by the quantity, the time, the duration of light exposure and its spectrum. In elderly people, high levels of natural light increase the level of melatonin.

Finally, ageing implies eyes-related diseases and disorders, such as loss of vision and blindness. In particular, loss of vision is the intermediate condition between normal vision (20/20) and blindness (3/60) (WHO, 2011). 


\section{The Human Centric Lighting Approach: Definition, Design Opportunities and Potential Limitations}

A 2013 joint study of LightingEurope and the German Electrical and Electronic Manufacturers' Association (ZVEI) promoted the Human Centric Lighting (HCL) as a design-oriented approach useful to improve the human wellbeing, people's concentration, safety and efficiency in workplaces (Kearney, 2013). This study affirms that HCL can support healing processes and prevention of chronic diseases among persons with irregular daily routines or in elderly care. As reported by Heller (2016), HCL centers on the relationship between light and levels of wellbeing, where the effects on circadian rhythms can be correlated to specific light conditions.

Compared to traditional design approach, HCL considers both visual and nonvisual effects of light - i.e. biological and emotive factors - rarely taken into account; this allows to have a quasi-total control on lighting sources, including: direction, intensity, chromatic gradients and exposure time. Therefore, HCL is not a productcentered design approach; it holistically considers people in their environments, taking into account their activities, tasks, wishes and human conditions, to generate smart solutions that meet human's physiological aspects and new technological advances.

Even though HCL is still less used in Design discipline, it offers a large number of benefits. A recent study (de Kluizenaar et al., 2016) has shown strengths and main difficulties for the development and the diffusion of HCL; study's results are synthetically discussed below.

A first chance concerns the creation of customized systems of smart lighting solutions. Stakeholders have expressed the desire to have functional solutions, but also upgradable and implementable over time. This factor could improve, for example, the 'smart applications' sector (i.e. using Bluetooth and Wi-Fi, lighting systems can be controlled via smartphones and home automation systems) and, then, the sector of green buildings using systems for energy efficiency that mitigate the economic and environmental impacts.

A second promising chance concerns the development of biologically effective lighting solutions for human health and wellbeing. HCL could improve the wellbeing of patients in hospitals, humanizing the quality of sleep and preventing chronic diseases. For this reason, the personal care sector could probably be the most promising field of 
application for short-term experimentations. Personal care sector can best benefit from wellbeing-oriented lighting solutions aimed to support the active aging.

The extension of the HCL into work environments - i.e. offices, schools, etc. introduces a third chance, which concerns biologically effective lighting solutions for improving cognitive performances. In these contexts, full control of light can improve people's mood, satisfaction and productivity. For example, in schools light plays an important pedagogical role; it increases concentration and reduces errors.

Finally, light plays a strategic role in the creation of aesthetically pleasing and suggestive environments (i.e. architectural lighting). This fourth chance concerns the design and the development of pleasant spaces; for example: rooms with comfortable lights increase productivity; pleasant classrooms increase students' performance, etc.

On the other hand, the study conducted by de Kluizenaar et al. (2016) identified four main limitations related to the diffusion of HCL, which mainly concern: the lack of information and lack of awareness in the lighting industry, the lack of precise and quantified economic returns in the use of HCL-based products, the lack of standards and rules to support the technological spreading, and finally the lack of market insights, guidelines and evidences on the technological pros.

\section{Design and Development of an Age-Friendly Lighting System}

The design process used to develop a HCL-oriented age-friendly lighting system followed four different phases; moving from the analysis of end-users' abilities and needs, useful to know all user-centered aspects, to the design and implementation (i.e. ISO, 2010). The solution here presented, and referred to an academic trial, has been also verified using specific HF/E tests (anthropometric measurements and Universal Design checklist) in order to have the best solution possible (Deli, 2018).

\subsection{Analysis of Seniors' Abilities and Design Correlations}

The analysis of seniors' psychophysical conditions allowed to define a descriptive framework connecting human conditions with design implications and senior-centred needs. Such conditions (Table 1) have been used to describe the quality of seniors' 
interaction with products, in order to understand their needs and, from the design point of view, the nature of design requirements to be developed. The framework has been therefore developed using existing literature, standardization references (Denno et al., 1992; ISO, 2001; Farage et al., 2012) and participative research sessions with a sample of 12 potential stakeholders (co-design on lighting domain). Stakeholders' data have been later summarized and screened to detect harmonized needs for lighting domain.

Table 1 about here.

\subsection{Analysis of End-Users' Needs and Development of Product's Design} Requirements

From the previous analysis, and from the review of potential design implications related to their conditions, a meta-projectual analysis has been developed to connect the medical domain with the design one. Specifically, the 'Effects/Implication of Age' shown in Table 1 has been used to understand the end-users' needs and to develop a new class of design information (Table 2), composed by: 'Classes of Design Requirements' (left column) and 'Detailed HCL-Oriented Design Requirements and Recommendations for Lighting Companies/Designers' (right column). This analysis allowed to have a clear and detailed framework of design information useful to develop, in the next design phases, the design concept and the HCL-oriented design solutions. 'Recommendations for Lighting Companies/Designers' have been developed to be as scalable data for industry-related developments. Moreover, in this phase, relevant data belonging to Universal Design (Connell et al., 1997) and Design for Sustainability (Manzini and Vezzoli, 1998) domains have been used to have accurate information about end-users.

Table 2 about here.

\subsection{Development of the HCL-Based System}

The development of the HCL-Based System started considering the seniors' fundamental needs and, then, how to apply the list of 'Detaild HCL-Oriented Design 
Requirements'. In this early design phase, the attention was addressed to the development of a set of basic elements to be refined later. This process has defined the five main elements of the lighting system: a base, a spotlight, a light diffusor, a lighting system and a set of controls (Deli, 2018).

As shown in Figures 1 and 2, the HCL-Based System is composed by only four main elements: a reflective surface, a base, a rod and, finally, a lighting source linked to the rod. The reflective surface is a $13 \mathrm{~mm}$ thick composite sandwich composed by: painted anodized aluminium, PMMA (Polymethyl methacrylate) and aluminium framed MCPET (highly reflective PET foamed sheet). The base is made in black-painted anodized aluminium and contains an integrate solution to connect the rod and all electrical components like: power transformer, $\mathrm{COB}$ (Chip on Board used for the dynamic regulation of LEDs) ventilation slots, etc. The rod, made in black-painted anodized aluminium, is $25 \mathrm{~mm}$ diameter and contains two light sources: the first one is a vertical $750 \mathrm{~mm}$ light diffusor and the second one is a $90 \mathrm{~mm}$ horizontal light diffusor. All controls can be regulated in height - between 950 e $1110 \mathrm{~mm}$ - to meet all anthropometric conditions, and in depth $-350 \mathrm{~mm}$ - using an electric rail. The overall height $-1800 \mathrm{~mm}$ - has been chosen both to meet all anthropometric conditions and to create an elegant solution for any domestic environment. In general, the idea was to create a low thickness senior-friendly solution.

Figure 1 about here.

Figure 2 about here.

\subsection{Anthropometric Measurements and Age-Friendly Design Constrains}

The early concept design has been verified for anthropometry standards using one of the most used reference for Industrial Design discipline (Pheasant, 1996), which has allowed to perfect the dimensions of all components with which seniors will directly interact (i.e. knobs, connectors, etc.) (Figure 3). In terms of anthropometric verification, the populations - percentile (\%ile) - used as for references were:

- $99 \%$ ile American elderly men aged 65 to 79, used for the product's sizing (min. size). 
- $1 \%$ ile American elderly women aged 65 to 79 , used for the product's sizing (max. size).

- $\quad 99 \%$ ile American elderly men aged 65 to 79 and $1 \%$ ile American elderly women aged 65 to 79 used for the control sizing (max. and min. size).

- $99 \%$ ile American elderly men aged 65 to 79 and $1 \%$ ile American elderly women aged 65 to 79 used for the sizing of all surfaces, lighting systems and handling objects (i.e. knobs, connectors, rods, etc.) (max. and min. size).

Figure 3 about here.

Later, the measurements refined through anthropometric tests have been combined with the original lighting system to obtain a coherent solution that meet both human insights (i.e. HCD) and technological components (technology-push approach). As last verification, we used the Universal Design checklist (CUD NCSU, 2002) to validate the HCL-Based System even with critical end-users' conditions. This confirmed the coherence of the solution even for the Universal Design principles.

\subsection{Technological Implementation and Full Simulations}

In the last design phase, some simulations have been developed to tests the different lighting qualities and conditions of use of the HCL-Based System. Such simulations were addressed to understand the visual pleasantness of lighting sources in all potential domestic uses. The aim of this phase was to verify the lighting effects with the HCL approach in order to confirm the design approach used or, at least, to implement specific elements if needed. From the technological implementation of all system's elements, some provisional conditions - scenarios of use - have been created to show the qualitative and quantitative performance of all lighting sources. In particular four main simulations have been developed for:

- Standby/Activation lights: an integrated twilight sensor detects the amount of light and, when needed, automatically activates the product - it reveals the presence of the lighting system through the activation of the controls on the PMMA shell. 
- Side light (5 lm ca.): it provides night lighting in case end-users need to move in the dark. The lighting system illuminates the floor - and adjacent furniture - to show the safest way or the nearest switch, reducing the risk of falls.

- Diffused light sources: spotlights vary from $800 \mathrm{~lm}$ to $1600 \mathrm{~lm}$. The colour temperature used is D65 - daylight 6500 - equivalent to a solar light simulation of $6500{ }^{\circ} \mathrm{K}$. The controls contained in the lighting system allow to vary the colour temperature from $4000{ }^{\circ} \mathrm{K}$ to $2700{ }^{\circ} \mathrm{K}$.

- Direct light sources: from $400 \mathrm{~lm}$ to $600 \mathrm{~lm}$.

Some full simulations have been used to set the overall product's aesthetics, as well as to have early feedbacks from potential customers in relation to potential domestic contexts of use (Figure 4).

Figure 4 about here.

\section{Conclusions and Discussion}

Ageing of world population is producing remarkable effects in the design and development of personal products; as reported by many studies, it is currently forcing designers and companies to rethink and approach the social issues with new tools and design approaches. As the need of lighting solutions is a basic factor for the everyday life of people, the 'seniors condition' is producing a new approach to market with new and proactive solutions based on inclusive-oriented approach.

$\mathrm{HCL}$ is a fast-growing approach that considers both visual and non-visual aspects of light, allowing to conceive new products able to meet all psychophysiological conditions of all end-users. Compared to the seniors' condition, HCL can play a crucial role in the design and in the selling of smart human-centred products.

This paper has shown that the HCL approach can be used in the design of highly usable and eco-efficient domestic lighting solutions that meet the seniors' needs and abilities. As it has been discussed in the first part of this paper, the seniors' psychophysiological conditions are strongly influenced by light condition, involving visual, non-visual, ergonomic and design aspects. So, the research here presented demonstrates that the development of lighting solution for people aged 65 , or more, is a 
complex issue, but the use of recent design approaches, the investigation of current advances in medical and technological fields, and the use of the HCL approach can help all designers in the design of elegant eco-efficient and effective age-friendly solutions able to meet both human needs and industrial production.

Finally, evidences have shown that HCL can be considered in line with traditional aims of $\mathrm{HF} / \mathrm{E}$ discipline, while it has been possible to use and adapt traditional tests and design approaches with new socio-demographic issues.

\section{Acknowledgements}

This paper shows the results of the M.Arch. Thesis entitled 'Human Centric Lighting Approach: Design of a Lighting System for the Elderly Sector', developed in the Department of Architecture of the University of Chieti-Pescara in Italy, by Aldo Deli (Student), under the supervision of Professor Massimo Di Nicolantonio (Advisor). While all authors have contributed to the development of this research, the writing of various paragraphs can be attributed to Massimo Di Nicolantonio for Paragraphs 5 and 6; to Emilio Rossi for Abstract, Paragraphs 3 and 7; to Aldo Deli for Paragraphs 2 and 4; and to Antonio Marano for Paragraph 1.

\section{References}

Anderson, G. 2006. Product Design for the Elderly. Retrived from: https://gizmodo.com/169097/frog-design-mind.

Bernanrd, S., D. Gonze, B. Čajavec, H. Herzel and H. Kramer. 2007. SynchronizationInduced Rhythmicity of Circadian Oscillators in the Suprachiasmatic Nucleus. PLoS Computational Biology. 3(4): e68 DOI: https://dx.doi.org/10.1371/journal.pcbi.0030068.

Blask, D., G. Brainard, R. Gibbons, S. Lockley, R. Stevens, and M. Motta. 2012. Light Pollution: Adverse Health Effects of Nighttime Lighting (Report 4 of the Council on Science and Public Health (A-12)). Retrieved from: http://circadianlight.com/images/pdfs/newscience/American-MedicalAssociation-2012-Adverse-Health-Effects-of-Light-at-Night.pdf. 
Brainard, G.C. and I. Provencio. 2008. Photoreception for the Neurobehavioral Effects of Light in Humans. Light and Engineering 16(1): 5-18.

Christoffersen, J. 2011. The Importance of Light to Health and Well-Being. Proceedings of the $4^{\text {th }}$ VELUX Daylight Symposium: 'Daylight in a Human Perspective'.

Collins, M.J., B. Brown and K.J. Bowman. 1989. Peripheral Visual Acuity and Age. Ophthalmic and Physiological Optics 9: 314-316.

Connell, B., M. Jones, R. Mace, J. Mueller, A. Mullick, E. Ostroff, J. Sanford, E. Steinfeld, M. Story and G. Vanderheiden. 1997. The Principles of Universal Design: Version 2.0. Raleigh, NC: The Center for Universal Design.

Davis, A.C., B. Ostri and Parving, A. 1990. Longitudinal Study of Hearing. Acta OtoLaryngologica 111(476): 12-22. DOI: https://doi.org/10.3109/00016489109127251.

de Kluizenaar, Y., R. Fazakas, L. Del Viva and C. Villegas Sanchez. 2016. Recommendations and Opportunities for Implementation of Human Centric Lighting: Accelerate SSL Innovation for Europe (Deliverable D3.6, part 1). s.1.: SSL-erate Consortium.

de Weerth, C., R.H. Zijl and J.K. Buitelaar. 2003. Development of Cortisol Circadian Rhythm in Infancy. Early Human Development 73(1-2): 39-52. DOI: https://doi.org/10.1016/S0378-3782(03)00074-4.

Deli, A. 2018. Human Centric Lighting Approach: Design of a Lighting System for the Elderly Sector. M.Arch. Dissertation, University of Chieti-Pescara, Italy. Denno, S., B.A. Isle, G. Ju, C.G. Koch, S.V. Metz, R. Penner, L. Wang and J. Ward. 1992. Human Factors Design Guidelines for the Elderly and People with Disabilities (Revision 3 Draft, SSDC-SYS/AI-C92-009). Minneapolis, MN: Honeywell SSDC.

Farage, M.A., K.W. Miller, F. Ajayi and D. Hutchins. 2012. Design Principles to Accommodate Older Adults. Global Journal of Health Science 2012 Mar 4(2): 2-25. DOI: https://doi.org/10.5539/gjhs.v4n2p2.

Gassmann, O. and G. Reepmeyer. 2011. Universal Design: Innovations for All Ages. In: Kohlbacher, F. and C. Herstatt (eds.). The Silver Market Phenomenon. Berlin, Heidelberg: Springer. DOI: https://doi.org/10.1007/978-3-642-14338$\underline{08}$. 
Hardeland, R., S.R. Pandi-Perumalb and D.P. Cardinali. 2006. Melatonin. The International Journal of Biochemistry \& Cell Biology 35(3): 313-316. DOI: https://doi.org/10.1016/j.biocel.2005.08.020.

Heller, M. 2016. Innovations in Lighting Technology Impact More Than Efficiency. Retrived from: https://www.aia.org/articles/20866-innovations-in-lightingtechnology-impact-mo:36.

Hilz, M.J., B. Stemper, F.B. Axelrod, E.H. Kolodny and B. Neundorfer. 1999. Quantitative Thermal Perception Testing in Adults. Journal of Clinical Neurophysiology 16(5): 462-471. DOI: https://doi.org/10.1097/00004691199909000-00008.

Hirsh, J., T. Riemensperger, H. Coulom, M. Iche, J. Coupar, and S. Birman. 2010. Roles of Dopamine in Circadian Rhythmicity and Extreme Light Sensitivity of Circadian Entrainment. Current Biology 20(3): 209-2014. DOI: https://dx.doi.org/10.1016\%2Fj.cub.2009.11.037.

Hornor, T. 2013. 10 Troublesome Colors to Avoid In Your Advertising. Retrived from: https://www.sitepoint.com/10-troublesome-colors-to-avoid-in-your-advertising/ ISO (International Organization for Standardization). 2001. Guidelines for Standards Developers to Address the Needs of Older Persons and Persons with Disabilities (ISO/IEC Guide 71:2001). Geneva: Switzerland.

ISO (International Organization for Standardization). 2010. Ergonomics of HumanSystem Interaction - Part 210: Human-Centred Design for Interactive Systems (ISO 9241-210). Geneva: Switzerland.

Kearney, A.T. 2013. Human Centric Lighting: Going Beyond Energy Efficiency (July 2013). Brussels: LightingEurope.

Lemmer, B. 2010. Circadian Rhythms. In: Stolerman I.P. (eds.) Encyclopedia of Psychopharmacology. Berlin, Heidelberg: Springer. DOI: https://doi.org/10.1007/978-3-540-68706-1.

Manzini, E. and C. Vezzoli. 1998. Lo Sviluppo di Prodotti Sostenibili: I Requisiti Ambientali dei Prodotti Industriali. Rimini: Maggioli Editore.

Mieczakowski, A.K. and P.J. Clarkson (eds.). 2013. Ageing, Adaption and Accessibility: Time for the Inclusive Revolution!. University of Cambridge: Engineering Design Centre. 
Moschis, G.P., E. Lee and A. Mathur. 1997. Targeting the Mature Market: Opportunities and Challenges. Journal of Consumer Marketing 14(4): 282-293. DOI: https://doi.org/10.1108/07363769710188536.

Pechacek, C., M. Andersen, and S.W. Lockley. 2013. Preliminary Method for Prospective Analysis of the Circadian Efficacy of (Day) Light with Applications to Healthcare Architecture. LEUKOS The Journal of the Illuminating Engineering Society 5(1): 1-26. DOI: https://doi.org/10.1080/15502724.2008.10747625.

Pheasant, S. 1996. Bodyspace: Anthropometry, Ergonomics and the Design of Work. London: Taylor \& Francis.

Pirkl, J.J. 1994. Transgenerational Desin: Products for an Aging Population. New York, NY: Van Nostrand Reinhold.

Pontes, A.L.B.d., R.C.G.J. Engelberth, E.d.S.Jr. Nascimento, J.C. Cavalcante, M.S.M.d.O. Costa, L. Pinato, C.A.B.d. Toledo and J.d.S. Cavalcante. 2010. Serotonin and Circadian Rhythms. Psychology \& Neuroscience 3(2): 217-228. DOI: http://dx.doi.org/10.3922/j.psns.2010.2.011.

Rossi, E. and P. Barcarolo. 2019. Design for the Mediterranean Social Inclusion: PAD. Pages on Arts and Design 16(Towards a New Agenda for Design in the Mediterranean Region): 13-34.

Seidel, D., K. Richardson, N. Crilly, F. E. Matthews, P.J. Clarkson and C. Brayne. 2010. Design for Independent Living: Activity Demands and Capabilities of Older People. Ageing \& Society 30(7): 1239-1255. DOI: https://doi.org/10.1017/S0144686X10000310

Scheuermaier, K., A.M. Laffan and J.F. Duffy. 2011. Light Exposure Patterns in Healthy Older and Young Adults. Journal of Biological Rhythms 25(2): 113122. DOI: https://doi.org/10.1177\%2F0748730410361916.

Srivastava, M., T. Abdelzaher and B. Szymanski. 2012. Human-Centric Sensing. Philosophical Transactions of The Royal Society A Mathematical Physical and Engineering Sciences 370(1958): 176-97. DOI: https://doi.org/10.1098/rsta.2011.0244.

CUD NCSU (The Center for Universal Design at the North Carolina State University). 2002. Guidelines for Use of the Principles of Universal Design (January 29, 1999. Revised September 9, 2002). Raleigh, NC: North Carolina State University. 
Ticleanu, C., S. King, P. Littlefair and G. Howlett. 2015. Lighting and Health. Bracknell: IHS BRE Press.

UN (United Nations). 2017. World Population Prospects: Key Findings and Advanced Tables (2017 Revision). New York, NY: United Nations

van Bommel, W. and G.J. van den Beld. 2004. Lighting for Work: A Review of Visual and Biological Effects. Lighting Research and Technology 36(4): 255-269. DOI: https://doi.org/10.1191/1365782804li122oa.

van de Kraats, J. and D. van Norren. 2007. Optical Density of the Aging Human Ocular Media in the Visible and the UV. Journal of the Optical Society of America A 24(7): 1842-1857. DOI: https://doi.org/10.1364/JOSAA.24.001842.

Veitch, J.A., D.W. Hine and R. Gifford. 1993. End Users' Knowledge, Beliefs, and Preferences for Lighting. Journal of Interior Design 19(2): 15-26. DOI: https://doi.org/10.1111/j.1939-1668.1993.tb00159.x.

Veitch, J.A. and R. Gifford. 1996. Assessing Beliefs About Lighting Effects on Health, Performance, Mood, and Social Behavior. Environment and Behavior 28(4): 446-470. DOI: https://doi.org/10.1177/0013916596284002.

Vezzoli, C. and Manizini, E. 2008. Design for Environmental Sustainability. London: Springer.

Warman, V.L., D.-J. Dijk, G.R. Warman, J. Arendt and D.J. Skene. 2003. Phase Advancing Human Circadian Rhythms with Short Wavelength Light. Neuroscience Letters 342(1-2): 37-40. https://doi.org/10.1016/S03043940(03)00223-4.

WHO (World Health Organization). 2011. International Statistical Classifcation of Diseases and Related Health Problems (ICD-10) (10 ${ }^{\text {th }}$ Revision, edition 2010). Geneva: World Health Organization.

Wirz-Justice, A., P. Graw, K. Kräuchi, A. Sarrafzadeh, J. English, J. Arendt J and L. Sand. 1996. 'Natural' Light Treatment of Seasonal Affective Disorder. Journal of Affective Disorders 37(2-3): 109-20.

Wirz-Justice, A. and C. Fournier. 2010. Light, Health and Wellbeing: Implications From Chronobiology for Architectural Design. World Health Design (January 2010): 44-49. 

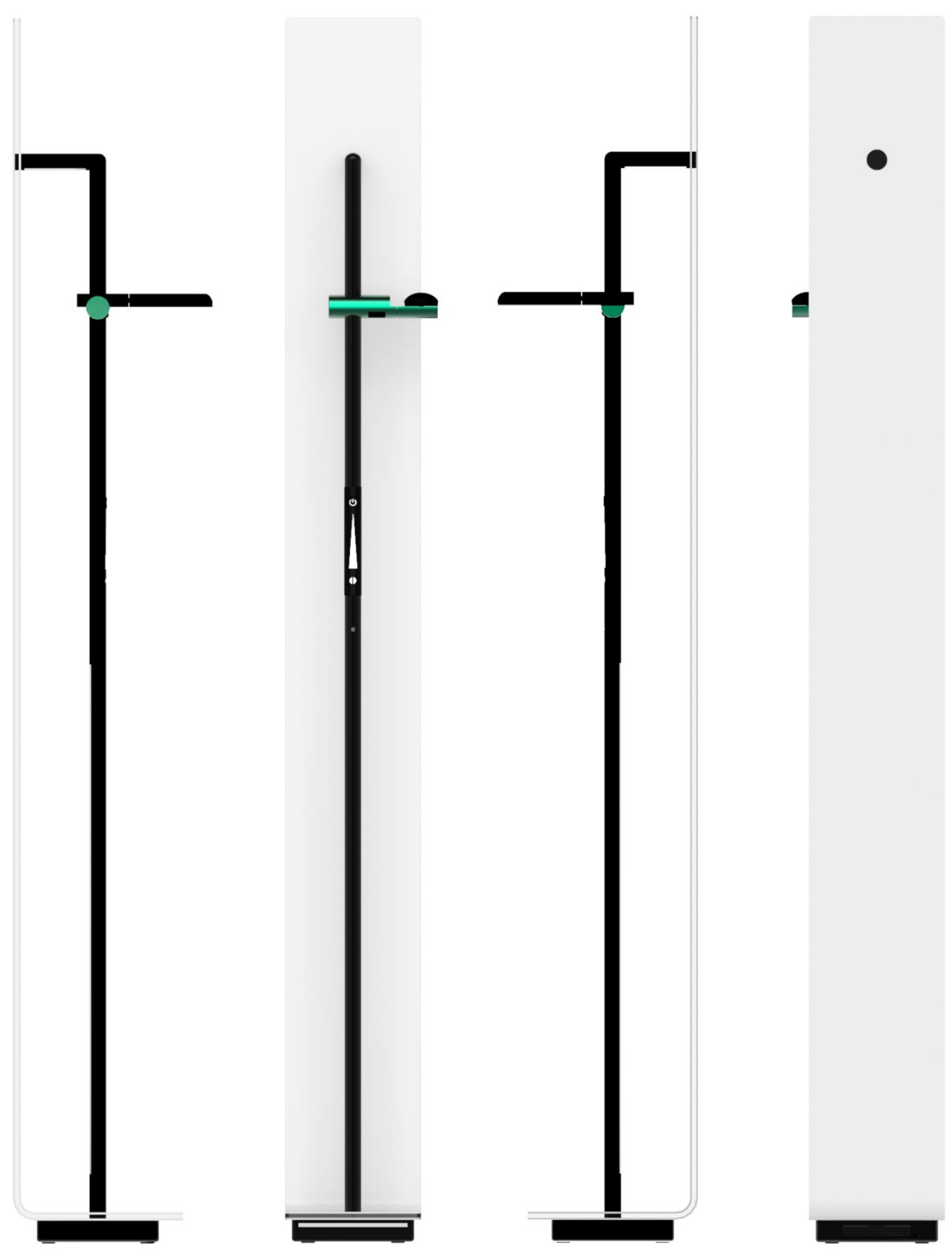

Figure 1. HCL-Based System: Four views. 


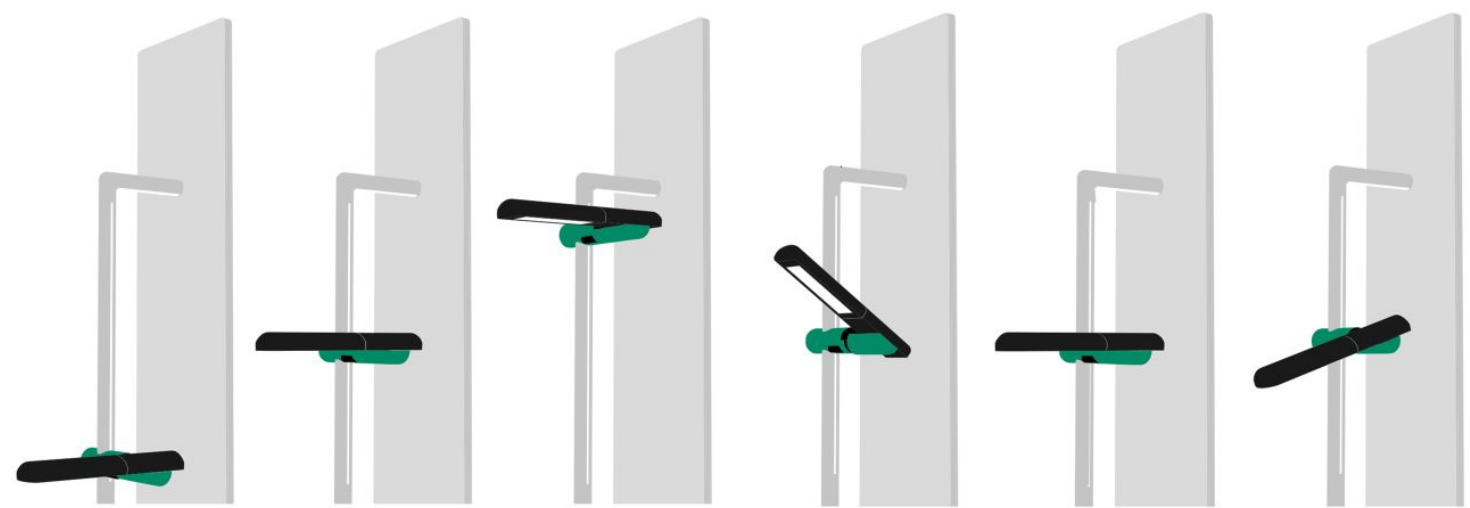

Figure 2. HCL-Based System: Movements of the lighting source.

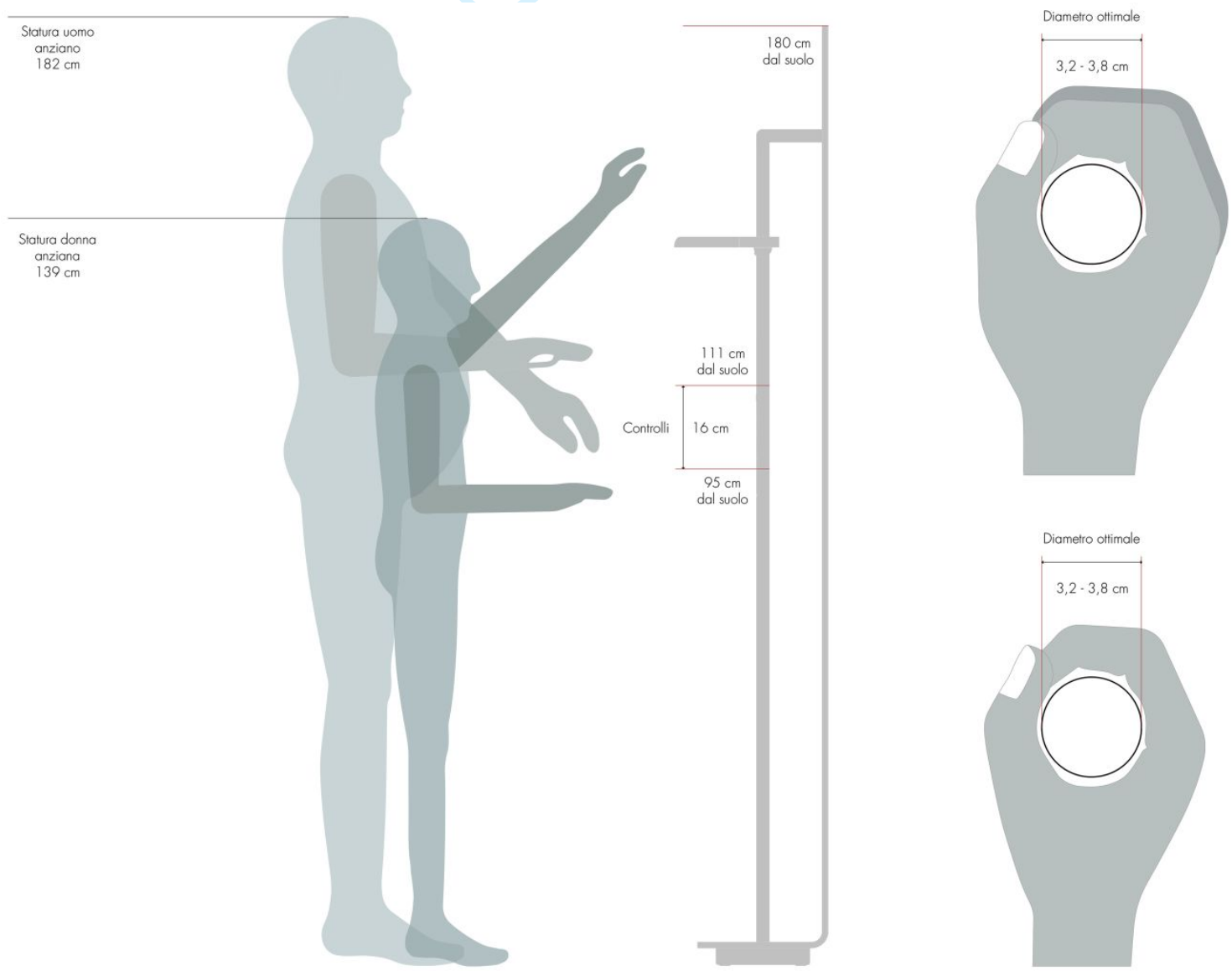

Figure 3. HCL-Based System: Anthropometric tests. 


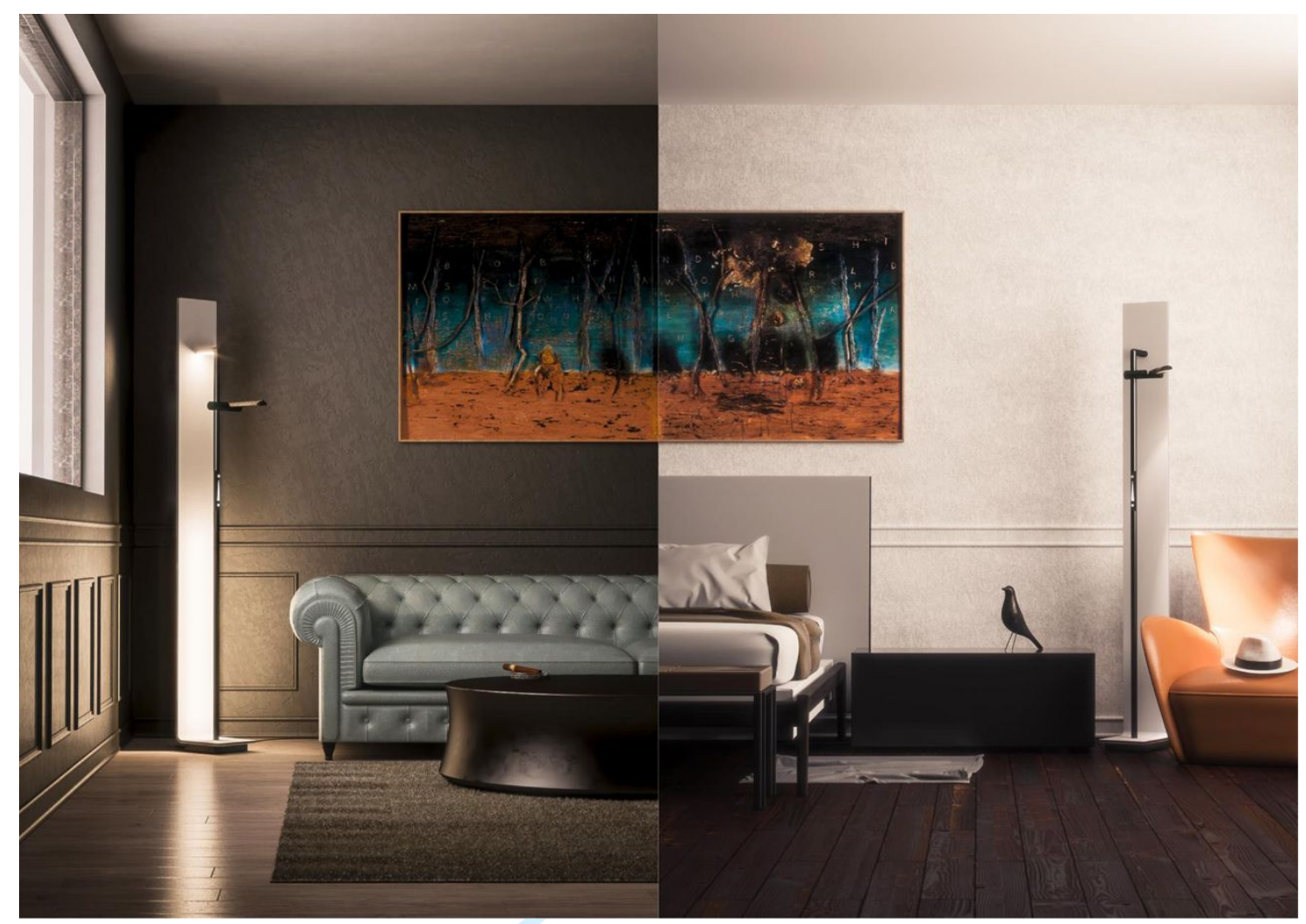

Figure 4. HCL-Based System: Full simulations in domestic contexts of use. 
Table 1. Analysis of seniors' abilities.

\begin{tabular}{|c|c|c|c|}
\hline \multirow[t]{2}{*}{ Skills } & \multicolumn{2}{|c|}{ Literature-based UCD Analysis } & \multirow{2}{*}{$\begin{array}{l}\text { Harmonized Senior- } \\
\text { Centred Needs (Co- } \\
\text { Design Research) - } \\
\text { Need of: }\end{array}$} \\
\hline & Effects of Age & $\begin{array}{l}\text { Risks and Design } \\
\text { Implications }\end{array}$ & \\
\hline $\begin{array}{l}\text { Eyesight } \\
\text { (Sensorial } \\
\text { Skills) }\end{array}$ & $\begin{array}{l}\text { Changes in the } \\
\text { physical structure of } \\
\text { eyes affect visual } \\
\text { functions, for } \\
\text { example: } \\
\text { - Loss of visual } \\
\text { acuity. } \\
\text { - Loss of vision at } \\
\text { short/long distance. } \\
\text { - Reduced field of } \\
\text { view. } \\
\text { - Colours perception. } \\
\text { - Depth of view } \\
\text { perception. } \\
\text { - Speed of adaptation } \\
\text { to different levels of } \\
\text { lights. } \\
\text { - Sensibility to light } \\
\text { (Pirkl, 1994). } \\
\text { Reduction of } \\
\text { (Collins et al., } \\
\text { 1989). }\end{array}$ & $\begin{array}{l}\text { People are more } \\
\text { exposed to risks, such } \\
\text { as: } \\
\text { - Low recognition of } \\
\text { sharped elements to } \\
\text { grab. } \\
\text { - Low perception of } \\
\text { unstable objects. } \\
\text { - Low recognition of } \\
\text { discontinued } \\
\text { surfaces and } \\
\text { obstacles. } \\
\text { - Low recognition of } \\
\text { flames and hot } \\
\text { surfaces. } \\
\text { - Low recognition of } \\
\text { corrosive elements } \\
\text { (unless evidenced). } \\
\text { Low recognition of } \\
\text { chromatic stimuli. }\end{array}$ & $\begin{array}{l}\text { - Have a semantic } \\
\text { concentration of } \\
\text { functions. } \\
\text { - Visual reduction in } \\
\text { the number of } \\
\text { controllers, and } \\
\text { their need. } \\
\text { - A decreasing in the } \\
\text { visual efforts. } \\
\text { - Use of solutions } \\
\text { having qualitative } \\
\text { and quantitative } \\
\text { 'semantic } \\
\text { coherence'. } \\
\text { - Use 'visually } \\
\text { characterized' } \\
\text { elements. }\end{array}$ \\
\hline $\begin{array}{l}\text { Hearing } \\
\text { (Sensorial } \\
\text { Skills) }\end{array}$ & $\begin{array}{l}\text { Decreased perception } \\
\text { of pure tones and low } \\
\text { sounds (circa }-2,5 \mathrm{~dB} \\
\text { each ten years up to } \\
\text { the age of } 55 \text {; circa - }\end{array}$ & $\begin{array}{l}\text { People could not be } \\
\text { able to hear } \\
\text { emergency sounds, } \\
\text { including high } \\
\text { frequency tones. }\end{array}$ & $\begin{array}{l}\text { - Have combined } \\
\text { communications } \\
\text { (i.e. } \\
\text { acoustic+visual). } \\
\text { - Differentiate }\end{array}$ \\
\hline
\end{tabular}




\begin{tabular}{|c|c|c|c|}
\hline & $\begin{array}{l}8,5 \mathrm{~dB} \text { each ten years } \\
\text { after the age of } 55 \\
\text { (Davis et al., 1990)). }\end{array}$ & & $\begin{array}{l}\text { artificial stimuli } \\
\text { (i.e. regular } \\
\text { warnings) from } \\
\text { natural ones } \\
\text { (random sounds). }\end{array}$ \\
\hline $\begin{array}{l}\text { Touch } \\
\text { (Sensorial } \\
\text { Skills) }\end{array}$ & $\begin{array}{l}\text { Seniors have lower } \\
\text { tactile sensitivity, so } \\
\text { they are more sensible } \\
\text { to cold temperature } \\
\text { and have a slower } \\
\text { reaction to high } \\
\text { temperatures. The } \\
\text { haptic perception, the } \\
\text { reaction on pressures } \\
\text { and the responses on } \\
\text { vibrations decrease } \\
\text { (Hilz et al., 1999). }\end{array}$ & $\begin{array}{l}\text { Seniors having haptic } \\
\text { hypersensitivity could } \\
\text { get hurt; such stimuli } \\
\text { can get can hurt people } \\
\text { with reduced haptic } \\
\text { sensitivity, if exposed } \\
\text { to long haptic } \\
\text { stimulation. Some } \\
\text { conditions decrease } \\
\text { the ability in grabbing } \\
\text { and handling. }\end{array}$ & $\begin{array}{l}\text { - Have 'confortable' } \\
\text { surfaces to } \\
\text { grab/handle (i.e. } \\
\text { soft, textured, etc.). } \\
\text { - Limit the time of } \\
\text { physical efforts. } \\
\text { - Limit the need to } \\
\text { move objects. } \\
\text { - Have 'enabling' } \\
\text { surfaces. }\end{array}$ \\
\hline $\begin{array}{l}\text { Taste and } \\
\text { Smell } \\
\text { (Sensorial } \\
\text { Skills) }\end{array}$ & $\begin{array}{l}\text { In principle, the ability } \\
\text { to recognise smells } \\
\text { decreases with age. }\end{array}$ & $\begin{array}{l}\text { Taste and smell losses } \\
\text { affect, for example, } \\
\text { the detection of toxic } \\
\text { materials and smells } \\
\text { from electrical } \\
\text { malfunctions. }\end{array}$ & - N/A*. \\
\hline $\begin{array}{l}\text { Balance } \\
\text { (Sensorial } \\
\text { Skills) }\end{array}$ & $\begin{array}{l}\text { Attention deficits and } \\
\text { sight limitations } \\
\text { reduce the ability to } \\
\text { prevent hazards and to } \\
\text { react in case of } \\
\text { instability. The } \\
\text { muscular weakness } \\
\text { contributes to the loss } \\
\text { of equilibrium. People } \\
\text { with vestibular and/or }\end{array}$ & $\begin{array}{l}\text { Discontinued surfaces, } \\
\text { obstacles and } \\
\text { protrusions can } \\
\text { generate falls; seniors } \\
\text { are more exposed to } \\
\text { domestic fall down. } \\
\text { Equilibrium issues } \\
\text { increase the fear to fall } \\
\text { down and affect the } \\
\text { personal }\end{array}$ & $\begin{array}{l}\text { - Have time to move } \\
\text { from point A to } \\
\text { point B., even using } \\
\text { 'enabling' surfaces } \\
\text { and/or solutions to } \\
\text { walk. } \\
\text { - Use surfaces and } \\
\text { paths that minimize } \\
\text { the physical efforts. } \\
\text { - Use paths that are }\end{array}$ \\
\hline
\end{tabular}




\begin{tabular}{|c|c|c|c|}
\hline & $\begin{array}{l}\text { with proprioception } \\
\text { problems are used to } \\
\text { compensate these } \\
\text { conditions with sight. }\end{array}$ & independence. & $\begin{array}{l}\text { confortable from } \\
\text { the synesthetic } \\
\text { point of view. } \\
\text { - Safety, dignity and } \\
\text { autonomy during } \\
\text { movements. }\end{array}$ \\
\hline $\begin{array}{l}\text { Dexterity } \\
\text { (Physical } \\
\text { Skills) }\end{array}$ & $\begin{array}{l}\text { The inability to } \\
\text { conjoin thumbs and } \\
\text { other fingers together, } \\
\text { or move them away. } \\
\text { Complex tasks like } \\
\text { push-on and rotate } \\
\text { may be painful, or } \\
\text { impossible. Seniors } \\
\text { suffering by } \\
\text { involuntary muscle } \\
\text { spasms can have } \\
\text { problems in the } \\
\text { pursuing of precision } \\
\text { tasks. }\end{array}$ & $\begin{array}{l}\text { This condition } \\
\text { influences the } \\
\text { dimension, the shape } \\
\text { and the position of } \\
\text { commands. People } \\
\text { with lower dexterity } \\
\text { can hurt themselves or } \\
\text { they could accidentally } \\
\text { activate commands. }\end{array}$ & $\begin{array}{l}\text { - Use of 'enabling' } \\
\text { controllers that } \\
\text { support imprecise } \\
\text { activities. } \\
\text { - Have an improved } \\
\text { relation between: a) } \\
\text { dimension of } \\
\text { controllers and b) } \\
\text { time needed for } \\
\text { their use. } \\
\text { Dexterity is relevant } \\
\text { for seniors, while } \\
\text { stakeholders have } \\
\text { reported that generally } \\
\text { it is not a serious } \\
\text { issue. }\end{array}$ \\
\hline $\begin{array}{l}\text { Handling } \\
\text { (Physical } \\
\text { Skills) }\end{array}$ & $\begin{array}{l}\text { Handling may be } \\
\text { affected by the } \\
\text { inability to } \\
\text { simultaneously use } \\
\text { both hands, or they } \\
\text { have to be moved in } \\
\text { confined spaces. A } \\
\text { lower level of } \\
\text { manipulations } \\
\text { generates slower times }\end{array}$ & $\begin{array}{l}\text { People with reduced } \\
\text { handling ability can } \\
\text { have accidents (i.e. } \\
\text { unboxing, fixing, etc.). } \\
\text { The solutions should } \\
\text { minimize such risks } \\
\text { and prevent wrong } \\
\text { actions. }\end{array}$ & $\begin{array}{l}\text { - Use of 'enabling' } \\
\text { controllers that } \\
\text { support imprecise } \\
\text { activities. } \\
\text { - Have an improved } \\
\text { relation between: a) } \\
\text { dimension of } \\
\text { controllers and b) } \\
\text { time needed for } \\
\text { their use. }\end{array}$ \\
\hline
\end{tabular}




\begin{tabular}{|c|c|c|c|}
\hline & of reactions and risks. & & $\begin{array}{l}\text { - Have 'confortable' } \\
\text { surfaces to } \\
\text { grab/handle (i.e. } \\
\text { soft, textured, etc.). } \\
\text { - Limit the time of } \\
\text { physical efforts. } \\
\text { - Limit the need to } \\
\text { move objects. } \\
\text { - Have 'enabling' } \\
\text { surfaces. } \\
\text { - Perform tasks that } \\
\text { improve the human } \\
\text { coordination. } \\
\text { - Perform tasks } \\
\text { minimize the errors, } \\
\text { and their effects. }\end{array}$ \\
\hline $\begin{array}{l}\text { Movement } \\
\text { (Physical } \\
\text { Skills) }\end{array}$ & $\begin{array}{l}\text { Movement limitations } \\
\text { affect the daily } \\
\text { activities, for example: } \\
\text { - Inability to move } \\
\text { masses on legs. } \\
\text { - Reduced speed of } \\
\text { walk and stride. } \\
\text { - Lower range of } \\
\text { knuckle } \\
\text { movements. } \\
\text { - Inability to perform } \\
\text { coordinated } \\
\text { movements. }\end{array}$ & $\begin{array}{l}\text { Seniors having } \\
\text { physical problems are } \\
\text { more exposed to } \\
\text { properly act in critical, } \\
\text { emergency or } \\
\text { unexpected situations. }\end{array}$ & $\begin{array}{l}\text { - N/A*. } \\
\text { Movement is relevant } \\
\text { for seniors, while } \\
\text { stakeholders have } \\
\text { reported that generally } \\
\text { it is not a serious issue } \\
\text { since they perform the } \\
\text { actions according to } \\
\text { their confidence in } \\
\text { doing movements. }\end{array}$ \\
\hline $\begin{array}{l}\text { Power and } \\
\text { Resistance } \\
\text { (Physical } \\
\text { Skills) }\end{array}$ & $\begin{array}{l}\text { Limitations of muscle } \\
\text { force generate physical } \\
\text { fatigue during the } \\
\text { extended use of }\end{array}$ & $\begin{array}{l}\text { Limitation of all } \\
\text { activities where the } \\
\text { physical strengths is } \\
\text { needed, including the }\end{array}$ & - $\mathrm{N} / \mathrm{A}^{*}$ \\
\hline
\end{tabular}




\begin{tabular}{|c|c|c|c|}
\hline & $\begin{array}{l}\text { products. The control } \\
\text { of passive movements } \\
\text { (i.e. gravity-related } \\
\text { actions) is affected. }\end{array}$ & $\begin{array}{l}\text { light handling for long } \\
\text { time. }\end{array}$ & \\
\hline $\begin{array}{l}\text { Intellect } \\
\text { (Cognitive } \\
\text { Skills) }\end{array}$ & $\begin{array}{l}\text { Seniors can have } \\
\text { difficulties to focus, } \\
\text { perform specific tasks } \\
\text { and move the attention } \\
\text { on various tasks. } \\
\text { Disorders of the } \\
\text { circadian rhythm make } \\
\text { people less vigilant. }\end{array}$ & $\begin{array}{l}\text { Several problems } \\
\text { related to: } \\
\text { - Comprehension of } \\
\text { products. } \\
\text { - Understanding of } \\
\text { tasks. } \\
\text { - Feedbacks } \\
\text { recognition. } \\
\text { - Understanding of } \\
\text { functioning. } \\
\text { - Perception of } \\
\text { product's effected } \\
\text { on personal level of } \\
\text { wellbeing. }\end{array}$ & $\begin{array}{l}\text { - Use of rhetorical } \\
\text { elements to recall } \\
\text { functions and } \\
\text { understandable } \\
\text { step-by-step } \\
\text { functions. } \\
\text { - Have hierarchical } \\
\text { functional } \\
\text { categories. } \\
\text { - Use of } \\
\text { comprehensive } \\
\text { semantics to } \\
\text { support the tasks' } \\
\text { recognition. } \\
\text { - Have 'enabling' } \\
\text { feedbacks. } \\
\text { - Have multiple } \\
\text { choice to } \\
\text { recall/understand } \\
\text { tasks. }\end{array}$ \\
\hline $\begin{array}{l}\text { Memory } \\
\text { (Cognitive } \\
\text { Skills) }\end{array}$ & $\begin{array}{l}\text { Lower cognitive skills } \\
\text { can generate mental } \\
\text { confusions. This } \\
\text { condition affects both } \\
\text { Short- and Long-Term } \\
\text { Memories. }\end{array}$ & $\begin{array}{l}\text { Problems related to } \\
\text { memory can generate } \\
\text { severe risks when } \\
\text { tasks to be performed } \\
\text { are incomplete or } \\
\text { when there is a } \\
\text { dangerous situation. } \\
\text { The solution must } \\
\text { always guarantee a }\end{array}$ & $\begin{array}{l}\text { - Use of rhetorical } \\
\text { elements to recall } \\
\text { functions and } \\
\text { understandable } \\
\text { step-by-step } \\
\text { functions. } \\
\text { - Have hierarchical } \\
\text { functional } \\
\text { categories. }\end{array}$ \\
\hline
\end{tabular}




\begin{tabular}{|c|c|c|c|}
\hline & & $\begin{array}{l}\text { safe and error-friendly } \\
\text { use. }\end{array}$ & $\begin{array}{l}\text { - Use of } \\
\text { comprehensive } \\
\text { semantics to } \\
\text { support the tasks' } \\
\text { recognition. } \\
\text { - Have multiple } \\
\text { choice to } \\
\text { recall/understand } \\
\text { tasks. }\end{array}$ \\
\hline $\begin{array}{l}\text { Language } \\
\text { and } \\
\text { Literacy } \\
\text { Rate } \\
\text { (Cognitive } \\
\text { Skills) }\end{array}$ & $\begin{array}{l}\text { Aging and speech are } \\
\text { directly connected; } \\
\text { seniors show } \\
\text { difficulties in } \\
\text { communicate what } \\
\text { they think. }\end{array}$ & $\begin{array}{l}\text { People having } \\
\text { difficulty in linguistic } \\
\text { expressions are more } \\
\text { exposed to risks, if } \\
\text { unable to understand } \\
\text { relevant instructions of } \\
\text { alert signals. }\end{array}$ & $\begin{array}{l}\text { - Have/use visually } \\
\text { enhanced controls. } \\
\text { - Clearly understand } \\
\text { complex functions } \\
\text { in relations to tasks } \\
\text { to be performed. } \\
\text { - Know the utility of } \\
\text { unusual commands, } \\
\text { and their benefits. }\end{array}$ \\
\hline
\end{tabular}


Table 2. Design requirements and related detailed HCL-oriented design requirements.

\begin{tabular}{|c|c|}
\hline $\begin{array}{l}\text { Groups of Design } \\
\text { Requirements and their } \\
\text { Definitions }\end{array}$ & $\begin{array}{l}\text { Detailed HCL-Oriented Design Requirements and } \\
\text { Recommendations for Lighting Companies / Lighting } \\
\text { Designers }\end{array}$ \\
\hline $\begin{array}{l}\text { Aesthetical/Morphologic } \\
\text { al Design Requirements } \\
\text { (Distinctive Shapes and } \\
\text { Affordance) } \\
\text { Def.: Make easy the } \\
\text { formal and the } \\
\text { functional } \\
\text { comprehension of the } \\
\text { product and all its parts. }\end{array}$ & $\begin{array}{l}\text { - Distinctive shapes allow to recognise the product, its } \\
\text { parts and the functioning (self-explanation of use), for } \\
\text { example: } \\
\text { ○ Distinctive shapes help the recognition of } \\
\text { product's parts and, indirectly, their functions. } \\
\text { - Distinctive shapes increase the level of security } \\
\text { preventing misuses. } \\
\text { Distinctive shapes support the maintenance } \\
\text { processes and the overall product's functioning. } \\
\text { Distinctive shapes have to be coherent with } \\
\text { semantic properties (i.e. visual dimensions and } \\
\text { weight). } \\
\text { elements, the overall shape must be self-explicative. } \\
\text { The product must not appear like 'designed for seniors' } \\
\text { (prevention of social stigmas and coherence with all } \\
\text { markets); as a general rule: } \\
\text { autonomous assembling, even by non-trained } \\
\text { isive shapes improve the processes of } \\
\text { people. }\end{array}$ \\
\hline
\end{tabular}




\begin{tabular}{|c|c|c|}
\hline & 0 & $\begin{array}{l}\text { life. } \\
\text { Products 'designed for' have a lower affordance } \\
\text { and generates a poor user engagement. }\end{array}$ \\
\hline $\begin{array}{l}\text { Def.: Make easy the } \\
\text { chromatic recognition } \\
\text { and the psycho- } \\
\text { perceptive comfort. }\end{array}$ & - Imp & 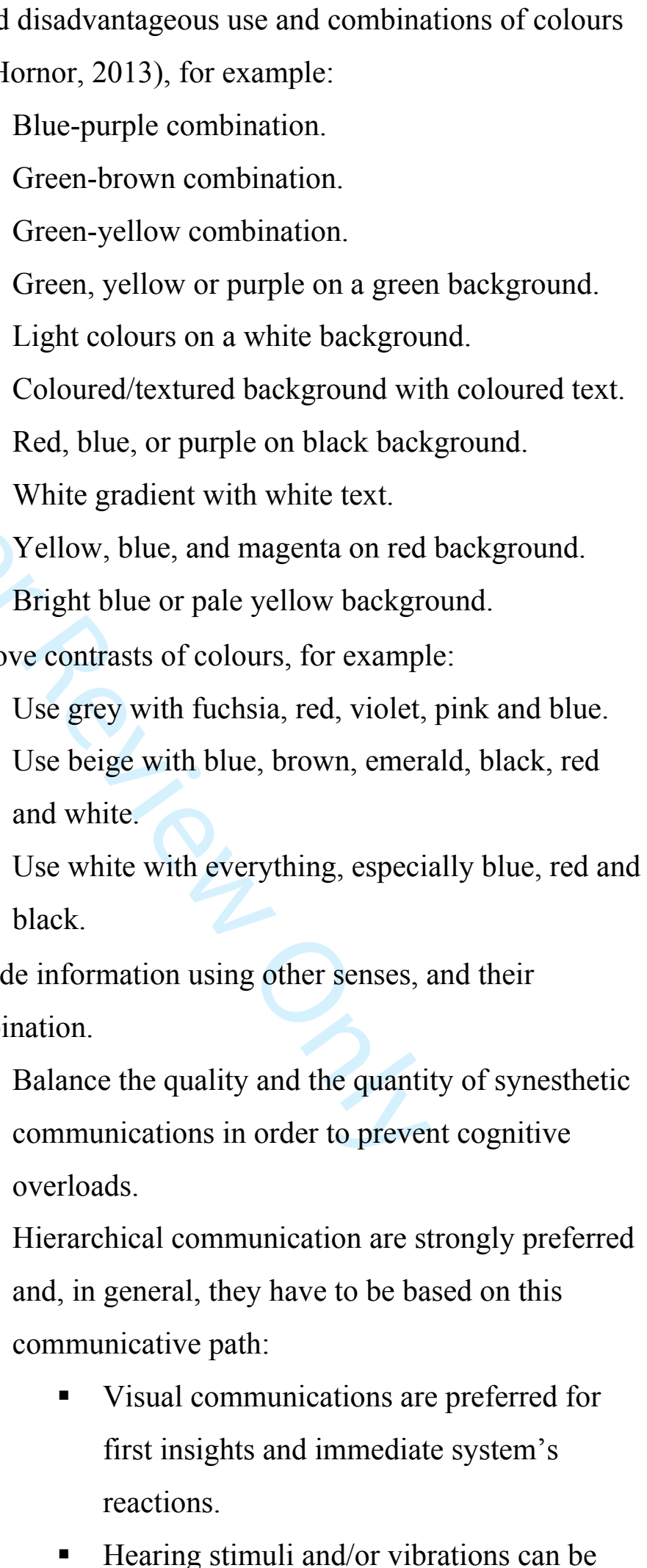 \\
\hline
\end{tabular}




\begin{tabular}{|c|c|}
\hline & $\begin{array}{l}\text { used to give consistency to visual messages } \\
\text { (i.e. feedbacks). } \\
\text { - Complementary stimuli can be used to give } \\
\text { completeness to previous stimuli. } \\
\text { - } \text { Olfactory stimuli can be used pay a strong } \\
\text { attention to the system's coherence, in order } \\
\text { to prevent misunderstandings and warnings. } \\
\text { - Prefer short wavelengths colours: } \\
\text { o Prefer colour range from violet ( } \sim 450-400 \mathrm{~nm}) \text { to } \\
\text { cyan }(\sim 520-490 \text { nm). } \\
\text { - In general, prefer blue-related colour tones. } \\
\text { Foreground elements must be clearly perceptible from } \\
\text { background. }\end{array}$ \\
\hline $\begin{array}{l}\text { Technological Design } \\
\text { Requirements } \\
\text { (Dimension and Weight) } \\
\text { Def.: Product's lightness } \\
\text { and physical } \\
\text { compactness. Materials } \\
\text { suitable for all uses. }\end{array}$ & $\begin{array}{l}\text { - Product's dimension and weight must allow the handling, } \\
\text { reducing the physical effort needed, for example: } \\
\text { Product's dimension has to be consistent with the } \\
\text { lighting functioning (i.e. actuation, transportation, } \\
\text { moving, maintenance, etc.). } \\
\circ \text { Product's dimension has to be consistent with the } \\
\text { effects generated by the lighting source. } \\
\text { Product's dimension has to be coherent with the } \\
\text { 'no-redundancy' design criterion. } \\
\text { Product's weight has to be coherent with the } \\
\text { 'movability' criterion (i.e. the more the product } \\
\text { needs to be moved, the less it must weight). } \\
\text { Product's actuation has to be physically calibrated } \\
\text { to seniors' physical capability. } \\
\text { The product must be compact. } \\
\text { As a general rule, compact products are perceived } \\
\text { as more user-friendly than large products; } \\
\text { especially for seniors, this design requirement is } \\
\text { important to establish first insights for 'autonomy } \\
\text { of use' and 'usability'. }\end{array}$ \\
\hline
\end{tabular}




\begin{tabular}{|c|c|}
\hline & $\begin{array}{l}\text { O Similar to 'Aesthetical/Morphological Design } \\
\text { Requirements'. } \\
\text { - The product must be composed by easy-to-use } \\
\text { components. } \\
\text { - Prefer safe and wear-resistant materials. } \\
\circ \text { According to the technological capability of } \\
\text { lighting companies/designers, this design } \\
\text { requirement implies to pay more attention on the } \\
\text { technological quality of the product, which will } \\
\text { generate a more competitive ROI. }\end{array}$ \\
\hline $\begin{array}{l}\text { Technological Design } \\
\text { Requirements (Materials } \\
\text { and Surface Finishes) } \\
\text { Def.: Choice of safe } \\
\text { surfaces, differentiated } \\
\text { according to the use and } \\
\text { the tactile perception. }\end{array}$ & $\begin{array}{l}\text { - Prefer antiskid surfaces to give a more efficient } \\
\text { handling/grip. } \\
\text { The 'antiskid quality' can be generated/improved } \\
\text { - Rany design strategies, including: } \\
\text { - Rationalised shapes and smooth } \\
\text { - } \quad \text { Use of layered parts using materials that } \\
\text { improve the grip. } \\
\text { - Differentiate surfaces' textures to improve the } \\
\text { identification of parts and controls, for example: } \\
\text { - Use colours - if/when possible - as communicative } \\
\text { solution to provide immediate information on } \\
\text { parts, functions and control elements. } \\
\text { of different materials, and their combinations (i.e. wood- } \\
\text { metal). } \\
\text { Use concentration/differentiation of textures and } \\
\text { masses to support direct/indirect communications. } \\
\text { Provide discontinuity in surfaces' texture in order } \\
\text { to provide semantic and haptic feedbacks. } \\
\text { - }\end{array}$ \\
\hline
\end{tabular}




\begin{tabular}{|c|c|}
\hline & $\begin{array}{l}\text { Haptic feeling is a powerful communicative } \\
\text { element that can be used to support } \\
\text { explicit/implicit messages (i.e. hard, soft, hot, cold, } \\
\text { regular, discontinue, large, big, etc.). }\end{array}$ \\
\hline $\begin{array}{l}\text { Functional Design } \\
\text { Requirements } \\
\text { (Alternative Shapes) } \\
\text { Def.: Possibility to } \\
\text { differentiate the } \\
\text { informative and } \\
\text { functional product's } \\
\text { outputs. }\end{array}$ & $\begin{array}{l}\text { - Provide a clear representation of the product (self- } \\
\text { explanation and presentation) to allow the understanding } \\
\text { of functions and the sensorial abilities needed. } \\
\text { ○ Similar to what has been described for } \\
\text { 'Aesthetical/Morphological Design Requirements'. } \\
\text { - Provide coherent informative inputs on the accessibility } \\
\text { of components (useful for people with disabilities). } \\
\text { Inputs have to be consistent, however: } \\
\text { - Avoid redundant informative inputs. } \\
\text { - Avoid random informative inputs (develop } \\
\text { and support coherent messages). } \\
\text { Balance time and intensity of informative }\end{array}$ \\
\hline $\begin{array}{l}\text { Functional Design } \\
\text { Requirements (Logical } \\
\text { Processes) } \\
\text { Def.: Simplicity of uses, } \\
\text { processes and feedbacks. }\end{array}$ & $\begin{array}{l}\text { - Improve end-users' problem-solving skills (useful for } \\
\text { people with disabilities) (i.e. set the design on end-users' } \\
\text { real abilities, develop the design of the lighting solution } \\
\text { involving stakeholders in the design process, use co- } \\
\text { design approach, etc.). } \\
\text { - Provide feedbacks (output) after all correct actions } \\
\text { (input). } \\
\text { - Promote the self-learning of tasks to be performed (i.e. } \\
\text { learning-by-doing). } \\
\text { Self-learning can be improved using semantic and } \\
\text { cognitive 'rewards' that produce engagement and } \\
\text { happiness. } \\
\text { Self-learning of tasks can be easily supported } \\
\text { developing expectation-based routines } \\
\text { (improvement of cause-effect process). } \\
\text { Self-learning has not to be redundant, or perceived }\end{array}$ \\
\hline
\end{tabular}




\begin{tabular}{|c|c|}
\hline & as such. \\
\hline $\begin{array}{l}\text { Functional Design } \\
\text { Requirement } \\
\text { (Multitasking) } \\
\text { Def.: Minimum cognitive } \\
\text { efforts needed focused } \\
\text { on functioning of } \\
\text { product. }\end{array}$ & $\begin{array}{l}\text { Avoid and prevent multitasking activities. In general } \\
\text { multitasking is not a bad design strategy; however the } \\
\text { senior condition imposes to reflect on the density of } \\
\text { multitasking activities to be performed by end-users } \\
\text { (amount of tasks per time needed for their fulfilment). }\end{array}$ \\
\hline $\begin{array}{l}\text { Usability-related Design } \\
\text { Requirements } \\
\text { (Effectiveness) } \\
\text { Def.: Make easy the } \\
\text { grab, the handling and } \\
\text { the control of the } \\
\text { product. }\end{array}$ & $\begin{array}{l}\text { - Develop coherent shapes to make easier the handling, for } \\
\text { example: } \\
\text { Increase the prehensility of product and product } \\
\text { parts in order to give autonomy and satisfaction } \\
\text { during the use. } \\
\text { Concentrate weights and masses in order to } \\
\text { balance the stability of the product, as well as its } \\
\text { morphological coherence. } \\
\text { - Controls should allow a comfortable grip, avoiding the } \\
\text { torsions of wrists, for example: } \\
\text { Levers and buttons are preferred. } \\
\circ \text { Textured surfaces are preferred to increase the grip } \\
\text { and help to modulate the force needed. } \\
\text { Controls should be distant to avoid mutual } \\
\text { interference and their actuation must be revealed } \\
\text { by multisensory feedbacks. } \\
\text { the solution must prevent the repetition of unnecessary } \\
\text { tasks. }\end{array}$ \\
\hline $\begin{array}{l}\text { Usability-related Design } \\
\text { Requirements } \\
\text { (Efficiency) } \\
\text { Def.: Make easy the use } \\
\text { of unmovable and }\end{array}$ & $\begin{array}{l}\text { - Make the product usable, movable and manageable even } \\
\text { by people with physical impairments. } \\
\text { - Create recognizable and accessible controls. } \\
\circ \text { Controls must be easy-to-grab, flexible, adaptable } \\
\text { and usable with one hand. } \\
\circ \text { Where possible, organise all controls in thematic }\end{array}$ \\
\hline
\end{tabular}




\begin{tabular}{|c|c|}
\hline $\begin{array}{l}\text { cinematic parts (and } \\
\text { their caught). }\end{array}$ & groups. \\
\hline $\begin{array}{l}\text { Def.: Give the chance to } \\
\text { have normal and/or } \\
\text { optimal light condition } \\
\text { in any circumstance, and } \\
\text { for all activities. Use of } \\
\text { correct surfaces for } \\
\text { direct/indirect lights. }\end{array}$ & $\begin{array}{l}\text { - Lights have to highlight relevant details to reveal } \\
\text { potential obstacles/barriers. } \\
\text { ○ If needed, lights can be used to highlight obstacles } \\
\text { and that could affect the human safety, as well as } \\
\text { the overall functioning stability. } \\
\text { Lights can be used as indirect elements to support } \\
\text { and strengthen the 'safety level' in any operational } \\
\text { context. } \\
\text { - Instructions and controls have to be always readable. } \\
\text { Balance the lighting effects and avoid the use of } \\
\text { reflective surfaces in order to prevent glares and sharp } \\
\text { shadows, for example: } \\
\text { Prefer distributed low intensity light sources. } \\
\text { Prevent sudden changes in light levels, to give eyes } \\
\text { the right time of adaption. }\end{array}$ \\
\hline $\begin{array}{l}\text { Perception-related } \\
\text { Design Requirements } \\
\text { (Temperature) } \\
\text { Def.: Protection from } \\
\text { excessively hot or cold } \\
\text { components. }\end{array}$ & $\begin{array}{l}\text { - All touchable surfaces must not be too hot or too cold. } \\
\text { - Use high thermal dissipation materials. } \\
\text { - Make evident the parts where temperature is hot or cold. } \\
\text { - Too hot or too cold surfaces must not be reachable by } \\
\text { hands and body parts, neither accidentally. }\end{array}$ \\
\hline $\begin{array}{l}\text { Def.: Use of proper } \\
\text { sounds to guarantee } \\
\text { comfortable acoustic } \\
\text { levels. }\end{array}$ & $\begin{array}{l}\text { - Sounds have to be clearly perceived and ambient noise } \\
\text { must be reduced (frequencies between } 500 \mathrm{~Hz} \text { and } 2000 \\
\mathrm{~Hz} \text { are preferred). } \\
\text { ○ When needed/possible, the use } \geq 60 \mathrm{~dB} \text { sounds is } \\
\text { highly preferred. } \\
\text { - Avoid unexpected and high frequencies. } \\
\text { order to give semantic consistency to any action, both } \\
\text { positive (expected feedback) and negative (unwanted). }\end{array}$ \\
\hline
\end{tabular}




\begin{tabular}{|c|c|}
\hline & $\begin{array}{l}\text { - Where possible, integration with multisensory stimuli } \\
\text { (i.e. vibrations) is preferred. }\end{array}$ \\
\hline $\begin{array}{l}\text { Safety-related Design } \\
\text { Requirement (Stability) } \\
\text { Def.: Integrity and safety } \\
\text { in the assembly of } \\
\text { products. }\end{array}$ & $\begin{array}{l}\text { - The product must have a mechanical and electrical } \\
\text { stability during the use. }\end{array}$ \\
\hline $\begin{array}{l}\text { Safety-related Design } \\
\text { Requirement } \\
\text { (Assembly/Wrong Use) }\end{array}$ & $\begin{array}{l}\text { - The product should be always restored in its original } \\
\text { condition, even when it is improperly used/assembled. } \\
\text { Provide alternatives in the use and clear restore } \\
\text { processes that can be used to reset the overall } \\
\text { lighting system. } \\
\text { Use of semantic functions in order to support the } \\
\text { return to previous functioning status (i.e. use of } \\
\text { morphological incompatibilities, use of aesthetical } \\
\text { incompatibilities, etc.). }\end{array}$ \\
\hline $\begin{array}{l}\text { Def.: Make easy the } \\
\text { understanding of } \\
\text { packaging. Choice of } \\
\text { proper materials. }\end{array}$ & $\begin{array}{l}\text { - The packaging should use forms, dimensions and } \\
\text { materials coherent to allow the easy opening and the fast } \\
\text { closing. } \\
\circ \text { Avoid sharp edges and surfaces. } \\
\circ \text { Limit the number of containers. } \\
\circ \text { Make clear the identification of product's parts and } \\
\text { components, especially if the lighting solution has } \\
\text { to be assembled by customers. } \\
\circ \text { Use different materials that support the products' } \\
\text { characteristics (i.e. shockproof containers for } \\
\text { fragile components). } \\
\circ \text { Avoid packaging having reflective surfaces. } \\
\text { Reduce the physical efforts needed to open packaging } \\
\text { (i.e. pop-up boxes are preferred). }\end{array}$ \\
\hline $\begin{array}{l}\text { Design Requirements for } \\
\text { Maintenance (Ordinary }\end{array}$ & $\begin{array}{l}\text { - Design and use of standardized and interchangeable } \\
\text { elements, for example: }\end{array}$ \\
\hline
\end{tabular}




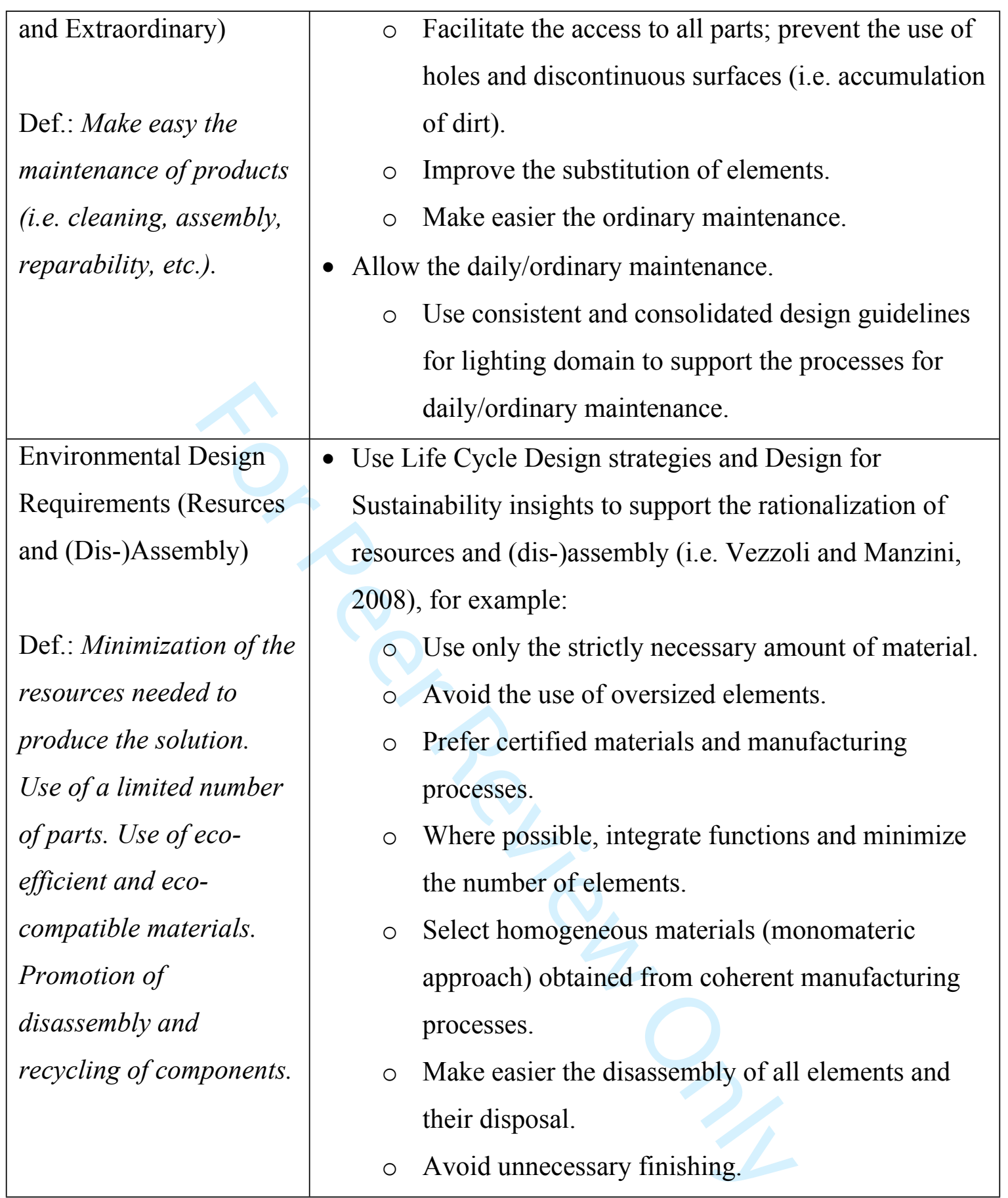

